\title{
EVALUASI PENYAJIAN LAPORAN KEUANGAN DINAS PEKERJAAN UMUM KOTA BITUNG BERDASARKAN PENERAPAN PERATURAN PEMERINTAH NO. 71 TAHUN 2010
}

\author{
Frenly Rombebunga ${ }^{1}$, David P.E Saerang ${ }^{2}$, Novi Swandari Budiarso ${ }^{3}$ \\ ${ }^{1,2,3}$ Fakultas Ekonomi dan Bisnis, Jurusan Akuntansi, Universitas Sam Ratulangi, Jl. Kampus Bahu, Manado, \\ 95115, Indonesia \\ E-mail : frenlyjuventus@gmail.com
}

\begin{abstract}
The purpose of this study is to determine whether the presentation of financial reports Municipal Public Works Bitung has been in accordance with Governmental Accounting Standard PP. 71 Year 2010. Type of research conducted is a case study. Data were obtained by interview, observation and documentation. The data taken is the history and development of agencies, agency goals, organizational structure of agencies, geographic conditions and boundaries, vision and mission of the institution, as well as Financial Reports Public Works Department of Bitung City. The analysis technique used is descriptive explorative analysis technique. The steps used in this study is to collect the required data, and then compare the financial report of Bitung City Public Works Department with the financial statements in accordance with the presentation of financial statements based on Governmental Accounting Standard PP. 71 Year 2010. The results showed that the Public Works Department of Bitung City has applied Standa $r$ Accounting Government PP. 71 Year 2010, although not yet optimal, because there are some points that are still incomplete in financial reporting such as Balance Over Change Budget Report (SAL). From twenty-three paragraphs regulating the financial report of Bitung City Public Works Department there are twenty paragas that have been in accordance with Governmental Accounting Standard PP. 71 of 2010. Three paragraphs that have not been applied are included in the Budget Breakdown of More Budget Changes (SAL) report.
\end{abstract}

Keywords: Government Accounting Standards, Department of Public Works, Financial Statements

\section{PENDAHULUAN}

Salah satu cara untuk melihat sistem pemerintahan baik ialah dengan memeperhatikan tata kelola pemerintahannya. Bila tata kelola baik (good governance) sistem pemerintahan pun berjalan baik. Sekarang pemerintah Indonesia selalu berupaya menaikan transparansi dan akuntabilitas pengelolaan keuangan negara. Standar Akuntansi Pemerintah harus membuat suatu syarat yang ada kekuatan hukum untuk berupaya meningkatkan laporan keuangan pemerintah di Indonesia. Dalam suatu instansi hal yang penting adalah pelaporan pertanggung jawaban kepada instansi pemerintah. Sebab instansi pemerintah sering disorot masyarakat. Kota Bitung merupakan provinsi yang ada Sulawesi Utara. Kota ini mempunyai kemajuan yang pesat sebab ada pelabuhan yang memajukan pembangunan. Kota ini berada di timur laut Tanah Minahasa. Kota Bitung merupakan kota industri, khususnya industri perikanan.

Salah satu Indikator kemajuan suatu kota ditentukan oleh pembangunan sarana dan prasarana. Pembangunan sarana dan prasarana disebuah kota dalam lingkup pemerintahan menjadi salah satu tanggung jawab dari Dinas Pekerjaan Umum. Sebagai suatu Satuan Kerja Perangkat Daerah (SKPD) dalam pelaksanaan tugasnya harus mengacu pada ketentuan peraturan perundang-undangan yang berlaku, diantaranya berkaitan dengan pengelolaan 
keuangan berdasarkan Standar Akuntasi Pemerintah (SAP). Langelo dkk (2015) pernah melakukan penelitian tentang suatu penerapan analisis tentang standart akuntansi pemerintah yang berbasis akrual yang penyajian dalam pelaporan keuangan pemerintahan kota Bitung, menyimpulkan bahwa penyajian laporan keuangan masih didasarkan pada PP No. 24 Tahun 2005 berbasis CTA (Cash Toward Acrual) dan berbasis kas menuju akrual. Hal ini memberikan hipotesis bahwa belum semua instansi pemerintah di kota Bitung telah menrapkan SAP berbasis akrual.

\section{TINJAUAN PUSTAKA}

Laporan Keuangan. Menurut Harahap (2007) pelaporan keuangan merupakan suatu bentuk pelaporan yang digambarkan suatu sifat keuangan dengan hasil kerja suatu instansi pada momentum yang telah ditetapkan ataupun dalam kurun waktu yang telah ditentukan. Bentuk hasi llaporan keuangan teridri dari Laporan Laba/Rugi serta neraca, atau hasil usaha, Arus Kas, Perubahan Posisi Keuangan.

Definisi Akuntansi. Akuntansi menurut Kieso (2008), akuntansi merupakan suatu identifikasi, ukuran dan informasi komunikasi keuangan mengenai entitas ekonomi untuk pihak yang bersangkutan. Akuntansi merupakan metode identifikasi, ukuran, catatan, serta laporan transaksi keuangan terhadap intansi demi informasi untuk mengambil suatu hasil ekonomi untuk pihak yang membutuhkan (halim dan kusufi 2012).

Akuntansi Sektor Publik. Mardiasmo, (2009) menerangkan bahwa pada periode yang relatif sedikit akuntansi sektor publik sudah menjalani kemajuan signifikan. Sekarang ini ada kepedulian yang besar pada praktik akuntansi untuk digunakan pada lembagalembaga pemerintah dibandingkan pada masa sebelumnya. Ada tuntutan lebih besar dari masyarakat agar dilakukan transparansi dan akuntabilitas oleh lembaga sektor publik.

Karakteristik Akuntansi Sektor Publik. Karakteristik akuntansi sektor publik (Mardiasmo 2009), Pemerintah membukukan anggaran ketika anggaran tersebut dibukukan, Pemerintah tak berorientasi laba, didalam akuntansi pemerintahan mungkin bisa digunakan satu atau lebih tipe dana, Akuntansi sektor publik membuat pembukuan terhadap pengeluaran aktiva dalam membangun gedung, serta mengadakan transpotasi didalam perkiraan neraca serta hasil operasional, Akuntansi sektor publik tidak mengetahui perkiraan aktiva dan laba yang ditahan didalam neraca.

Standar Akuntansi Pemerintahan. Standar merupakan ukuran yang dipakai sebagai patokan/acuan. Untuk mencapai tata kelola pemerintahan yang baik dalam aspek keuangan di daerah, pengelolaan keuangan berdasarkan standar yang ditentukan sangat penting untuk dilakukan/ diterapkan, diantaranya berkaitan dengan akuntansi. SAP ialah standar akuntansi yang lebih dulu ada di Indonesia yang mengontrol tentang akuntansi sektor publik. Karena terdapat standar ini, bahwa dalam pelaporan keuangan instansi ialah hasil terhadap sistem akuntansi agar bisa dipergunakan untuk media komunikasi diantara instansi dan stakeholders supaya meciptakan finansial negara yang akuntabel serta transparan (wijaya 2008). Sinaga (2005), Standar Akuntansi Pemerintah ialah untuk disatukan pemahaman kepada yang menyusun, yang menggunakan, serta yang mengauditor. Pemerintah pusat serta pemerintah daerah harus siap dalam penyajian pelaporan keuangan sesuai yang ada dalam SAP. Yang menggunakan laporan keuangan seperti legislatif agar menggunakan SAP agar bisa dipahami informasi yang ada dalam laporan keuangan agar supaya eksternal auditor (BPK) bisa menggunakan untuk menjadi kriteria didalam pelaksanaan audit. Sistem Akuntansi PPKD terdiri dari catatan, pengungkapan serta pengakuan atas Pendapatan Laporan Operasional dan Laporan Realisasi Anggaran, transfer, biaya, belanja aset, kewajiban, modal, penyesuaian dan koreksi, menyusun pelaporan keuangan PPKD dan menyusun pelaporan keuangan konsolidasi pemerintah daerah. Sistim akuntansi SKPD terdiri dari catatan, pengungkapan 
serta pengakuan terhadap pendapatan laporan operasional dan LRA, kewajiban, belanja, aset, modal, penyesuaian dan koreksi serta menyusun laporan keuangan SKPD.

Manfaat Standar Akuntansi Pemerintahan (SAP). Ada suatu fungsi dan keuntungan bisa diambil terhadap SAP ialah suatu pelaporan keuangan yang dibuat agar bisa membagikan suatu informasi keuangan jujur, terbuka serta lengkap untuk stakeholders. Oleh karena itu lingkup manajemen agar bisa mempermudah suatu guna dalam rencana, mengelola serta mengendalikan atas modal, beban, serta ekuitas dana pemerintah. Nordiawan (2006), ada suatu cara dalam melakukan suatu standar relevan pada praktek akuntansi pada instansi pemerintahan sudah dibuat yang sebaiknya oleh ikatan akuntan indonesia (IAI) dan pemerintah sendiri. Harus diperlukan suatu standar akuntansi yang sendiri atas keistimewaan signifikan diantara instansi pemerintah beserta perusahaan komersial, antara lain ialah ada tanggung jawab yang wajib kepada public yang lebih luas terhadap dana yang dimiliki. Mahsun (2006) mengatakan di Negara Kesatuan Republik Indonesia, bermacam-macam organisasi tergolong didalam lingkup sektor publik diantaranya pemerintah pusat dan daerah, organisasi bidang kesehatan, bidang pendidikan, serta organisasi massa. Dari pengertian tersebut maka bisa diambil kesimpulan bahwa pemerintah pusat atau daerah, adalah komponen dari organisasi pemerintahan, maka memerlukan pula standar akuntansi tersendiri. Demi menyelesaikan bermacam-macam keinginan yang timbul didalam laporan keuangan, akuntansi, serta audit di sektor publik, baik pemerintah pusat atau daerah yang ada di Negara Indonesia, sebab itu memerlukan standar akuntansi sektor publik yang valid, dibuat oleh sebuah komite SAP (Nordiawan,2007). SAP dibuat oleh Komite Standar Akuntansi Pemerintahan yang bebas serta ditetapkan sesuai Peraturan Pemerintah sudah lebih dulu mendapatkan pertimbangan terhadap Badan Pemeriksa Keuangan. Sebab itu, akuntansi basis akrual adalah media penunjang untuk diperlukan didalam transparasi dan akuntabilitas pemerintah (KSAP, 2006). Penjelasan tentang penggunaan akuntansi berbasis akrual didalam pelaporan keuangan pemerintah oleh Widjajarso (2008), diantara lain :

a. Akuntansi kas tidak membuat penjelasan yang layak, misal transaksi non kas dalam mengambil suatu hasil ekonomi, pejelasan atas hutang piutang, maka dari itu dalam menggunakan akuntansi akrual benar-benar disarankan.

b. Akuntansi akrual menyajikan suatu penjelasan yang akurat dalam menggambarkan anggaran sesungguhnya.

Akuntansi Berbasis Akrual. Bastian (2009), akuntansi berbasis akrual mencatat transaksi serta mengakui dan keadaan keuangan pada saat terjadi dan perolehan. Khan dan Mayes (2009) mengdefinisikan akuntansi basis akrual adalah metodologi pada akuntansi untuk mengakui suatu transaksi didasarkan pada aktifitas ekonomi tidak pada waktu menerima serta mengeluarkan kas.

Kajian Empiris. Bermacam-macam penelitian terhadap standar akuntansi pemerintah yang diterapkan pada pemerintahan. Langelo, Saerang, dan Alexander (2015) melakukan penelitian atas analisis penerapan SAP berbasis akrual didalam menyajikan pelaporan keuangan atas Kota Bitung. Maksud dari penelitian tersebut agar bisa memahami suatu pelaporan keuangan yang disajikan serta Kota Bitung siap untuk disajikan suatu pelaporan keuangan yang didasarkan SAP berbasis akrual. Demak, Sondakh dan Tangkuman (2015) yang meneliti tentang Penerapan PP no. 71 tahun 2010 didalam laporan akuntansi biaya Dinas Pekerjaan Umum Kota Kotamobagu tahun anggaran 2014. Tujuan dari penelitian ini untuk mengetahui bentuk penyajian dan pelaporan akuntansi belanja pada Dinas Pekerjaan Umum Kota Kotamobagu dalam penerapan PP No. 71 tahun 2010 untuk tahun anggaran 2014. Metode yang digunakan dalam penelitian ini adalah analisis deskriptif. Hasil penelitian ini yaitu tahun anggaran 2013 dan 2014 Dinas Pekerjan Umum Kota Kotamobagu dalam penyajian laporan belanja belum menerapkan PP No.71 Tahun 2010 tetapi telah sesuai 
dengan PP No. 24 Tahun 2005. Perbedaan terletak pada pencatatan transaksi belanja dan laporan keuangan yang dihasilkan. Sehingga diharap pada tahun anggaran berikutnya hendaknya Dinas Pekerjaan Umum sudah berdasarkan penuh terhadap Permendagri No. 64 Tahun 2013 serta menerapkan PP No. 71 Tahun 2010 didalam penyajian pelaporan keuangan khususnya mengenai akuntansi belanja.

\section{METODE PENELITIAN}

Jenis Penelitian. Jenis penelitian yang digunakan ialah studi kasus. Studi kasus merupakan penelitian yang memperhatikan suatu keadaan masalah yang berkaitan pada latar belakang serta kejadian saat ini dari objek serta subjek penelitian. Kemudian peneliti melakukan pengolahan data berupa laporan keuangan Dinas Pekerjaan Umum kota Bitung untuk selanjutnya dievaluasi kesesuaiannya dengan Standar Akuntansi Pemerintahan PP No. 71 Tahun 2010. Teknis analisis yang peneliti gunakan ialah deskriptif eksploratif.

Tempat dan Waktu Penelitian. Penelitian ini dilakukan di Dinas Pekerjaan Umum Kota Bitung dan waktu penelitian dimulai pada bulan Desember 2017.

\section{Subjek dan Objek Penelitian}

1. Subjek Penelitian. Dalam penelitian ini, subjek penelitiannya adalah pimpinan Dinas Pekerjaan Umum kota Bitung dan bagian keuangan Dinas Pekerjaan Umum kota Bitung.

2. Objek Penelitian. Dalam penelitian ini, yang menjadi objek penelitian adalah laporan keuangan Dinas Pekerjaan Umum kota Bitung periode tahun 2016.

Teknik Analisis Data. Peneliti menggunakan teknik analisis deskriptif eksploratif, ialah penggalian masalah yang terjadi dan atau untuk mendukung hipotesis (Supranto : 1997 dalam Suharso : 2009). Untuk menjawab permasalahan menggunakan cara sebagai berikut :

a. Mengumpulkan data berupa laporan keuangan Dinas Pekerjaan Umum kota Bitung yang terdiri LRA, LO,neraca, perubahan saldo anggaran lebih, arus kas, laporan perubahan akuitas serta CALK.

b. Membandingkan pelaporan keuangan Dinas Pekerjaan Umum kota Bitung dengan Standar Akuntansi Pemerintah PP No. 71 tahun 2010 tentang menyajikan pelaporan keuangan yang berupa dari 23 paragraf apa sudah sesuai atau tidak, dan jika tidak sesuai dijelaskan perbedaan yang ditemukan.

Sumber Data. Data yang digunakan dalam penelitian ini yaitu data primer. Data primer yaitu data yang diperoleh langsung dari objek penelitian, yang memerlukan pengolahan lebih lanjut oleh penulis. Data ini diperoleh melalui observasi langsung, wawancara, maupun dokumentasi.

\section{HASIL PENELITIAN DAN PEMBAHASAN}

\subsection{Hasil Penelitian}

Dinas Pekerjaan Umum Dan Penataan Ruang Kota Bitung sebagai salah satu instansi pemerintah daerah sesuai dengan tugasnya di bidang Pekerjaan Umum, Yaitu Infrastruktur Jalan dan jembatan, Sumber Daya Air dan Penataan Ruang di daerah terhadap hakikat memiliki suatu peranan yang sangat penting didalam membawa pembangunan bidang ekonomi, seimbang dalam mengembangkan daerah, merata dalam hasil pembangunan serta mengembangkan sosial budaya didalam rangka memenuhi sasaran pembangunan berkelanjutan. Dengan posisi strategis yang berada dibibir didalam kawasan Asia Pasifik serta mempunyai kondisi alam yang sudah sesuai sebagai pelabuhan laut yang alami yang berkelas Internasional sebagai potensi yang akan bisa dikembangkan sebagai "Pintu Gerbang Indonesia" dalam kawasan Asia Pasifik. Dengan posisi strategis ini Kota Bitung diharapkan mampu mengembangkan potensi daerah melalui pembangunan dan pengembangan sarana dan prasarana yang pada saat ini sudah cukup memadai.

Sajian Data. Dinas pekerjaan umum kota Bitung merupakan entitas dalam suatu akuntansi 
pada kota bitung yang diwajibkan dalam penyelenggaraan akuntansi serta melaporkan tanggung jawab terhadap pelaksanaan anggaran Pendapatan serta Belanja Negara dan membuat pelaporan keuangan terdiri dari Realisasi Anggaran, Neraca, dan Catatan atas Laporan Keuangan. Dinas pekerjaan umum merupakan entitas pelaporan serta seluruh SKPD adalah entitas dalam akuntansi menurut aturan undang-undang maka harus menyampaikan suatu pelaporan pertanggung jawaban atas pelaksanaan APBD ialah pelaporan keunagan SKPD. Berdasarkan pendapat dari staf keuangan, penyusunan laporan keuangan Dinas Pekerjaan Umum kota Bitung telah mengacu pada Standar Akuntansi Pemerintahan (PP 71 tahun 2010) karena mengikuti Permendagri. Staff keuangan juga terlihat sudah mengetahui sebagian besar penyusunan laporan keuangan berdasarkan 71 tahun 2010.

\subsection{Pembahasan}

1. Laporan Realisasi Anggaran. Berdasarkan SAP PP no. 71 tahun 2010 terdapat dua paragraf dalam mengatur tentang LRA, maka peneliti mengambil dua paragraf itu dalam menganalisis penerapan SAP PP No. 71 tahun 2010, yaitu paragraf 61 dan 62. Pada paragraf 61 Dinas Pekerjaan Umum Kota Bitung telah menerapkannya sesuai dengan SAP PP No. 71 tahun 2010 dimana LRA menyediakan alokasi, iktisar sumber serta penerapan sumber daya keuangan oleh pemerintah pusat dan daerah, didalam gambaran suatu tolak ukur diantara anggaran serta realisasi pada satu waktu pelaporan. Tetapi pada paragraf 62, Dinas Pekerjaan Umum Kota Bitung belum menerapkannya secara optimal. Pada paragraf 62 dijelaskan bahwa laporan realisasi anggaran didasarkan pada SAP PP No. 71 tahun 2010 harus memiliki unsur yang mencakup pendapatan-LRA, belana, transfer dan pembiayaan. Sedangkan pada realisasi pelaporan anggaran Dinas PU kota Bitung hanya menyajikan belanja-LRA saja.

2. Neraca. Dalam Standar Akuntansi Pemerintahan PP No. 71 Tahun 2010, Neraca dijabarkan dalam 14 paragraf yang kemudian terbagi dalam 3 bagian yaitu aset, kewajiban dan ekuitas. Neraca menggambarkan posisi keuangan suatu entitas pelaporan aktiva, beban serta ekuitas saat tanggal tertenu dijelaskan dalam paragraf 64 Standar Akuntansi Pemerintahan PP No. 71 tahun 2010. Pada realisasinya neraca laporan keuangan Dinas Pekerjaan Umum kota Bitung sudah digambarkan pada posisi keuangan suatu entitas pelaporan, kewajiban dan ekuitas pada tanggal tertentu. Neraca laporan keuangan Dinas Pekerjaan Umum kota Bitung menjelaskan tentang investasi jangka panjang yang diklasifikasikan menjadi investasi non permanen dan investasi permanen, keduanya dibuat dalam tujuan agar menghasilkan suatu manfaat ekonomi serta sosial untuk rentang waktu lebih dari satu periode akuntansi. Pada paragraf 71 Standar Akuntansi Pemerintahan PP No. 71 Tahun 2010 memaparkan unsur apa saja yang terdapat pada aset lancar, seperti perlatan, mesin, tanah gedung serta bangunan, jalan, irigasi, serta jaringan, aset tetap lain-lain serta konstruksi didalam pengerjaan. Unsur tersebut telah sesuai dengan yang tercantum pada aset lancar neraca laporan keuangan Dinas Pekerjaan Umum kota Bitung. Pada aset non lancar lainnya neraca Dinas Pekerjaan Umum kota Bitung telah sesuai dengan paragraf 72 Standar Akuntansi Pemerintahan PP No. 71 Tahun 2010, yaitu aset nonlancar lain diklasifikasikan sebagai aset lainnya, termasuk di dalamnya adalah aset tidak berwujud dan kemitraan dengan pihak ketiga. Pengelompokan kewajiban ialah meliputi kewajiban jangka panjang serta jangka pendek serta penjelasan pada masing-masing kewajiban terdapat pada paragraf 76 Standar Akuntansi Pemerintahan PP No. 71 Tahun 2010. Seperti terdapat pada neraca laporan keuangan Dinas Pekerjaan Umum Kota Bitung, hal teresbut dapat dilihat dari isi dari kewajiban jangka panjang maupun kewajiban jangka pendek. Saldo ekuitas di Neraca berasal dari saldo akhir ekuitas pada Laporan Perubahan ekuitas. Dalam neraca laporan keuangan Dinas Pekerjaan Umum Kota Bitung telah sesuai dengan Standar Akuntansi Pemerintahan PP No. 71 Tahun 2010. 
3. Laporan Operasional. Hasil yang diperoleh bahwa laporan operasional Dinas Pekerjaan Umum Kota Bitung telah sesuai dengan Standar Akuntansi Pemerintahan PP No. 71 Tahun 2010.

4. Laporan Perubahan Ekuitas. Pada realisasi pelaporan keuangan Dinas Pekerjaan Umum Kota Bitung telah sesuai dengan Standar Akuntansi Pemerintahan PP No. 71 Tahun 2010, karena telah menyajikan perubahan ekuitas berupa informasi kenaikan atau penurunan ekuitas tahun pelaporan dibandingkan tahun sebelumnya.

\section{KESIMPULAN DAN SARAN}

\subsection{Kesimpulan}

Hasil penelitian serta pembahasan berdasarkan pada laporan keuangan Dinas Pekerjaan Umum Kota Bitung pada tahun 2016, maka dapat diambil kesimpulan sebagai berikut :

Dinas Pekerjaan Umum Kota Bitung telah menerapkan Standar Akuntansi Pemerintahan PP No. 71 Tahun 2010, meskipun belum optimal, karena ada beberapa point yang masih belum lengkap dalam pelaporan keuangan seperti Laporan Perubahan Saldo Anggaran Lebih (SAL). Dari dua puluh tiga paragraf yang mengatur mengenai laporan keuangan Dinas Pekerjaan Umum Kota Bitung terdpat dua puluh paragaf yang telah sesuai dengan Standar Akuntansi Pemerintahan PP No. 71 Tahun 2010. Tiga paragraf yang belum diterapkan terdapat pada uraian Laporan Perubahan Saldo Anggaran Lebih (SAL).

\subsection{Saran}

1. Bagi Dinas Pekerjaan Umum Kota Bitung. Berharap kota bitung agar bisa dijadikan suatu pertimbangan dan masukkan didalam menyusun pelaporan keuangan Dinas Pekerjaan Umum Kota Bitung yaitu sebaiknya dalam penyusunan laporan keuangan agar diperlengkap.

2. Bagi peneliti selanjutnya. Penelitian ini diharapkan dapat dipergunakan untuk salah satu sumber refrensi serta menulusuri lebih dalam lagi suatu penjelasan yang dibutuhkan, agar mendapat hasil yang lebih baik serta melakukan penelitian lebih lanjut di instansi yang berbeda.

\section{DAFTAR PUSTAKA}

Bastian, Indra. 2009. Akuntansi Sektor Publik di Indonesia. BPEE. Yogjakarta.

Demak, D; Sondakh, J; Tangkuman, S. 2014. Penerapan PP No. 71 Tahun 2010 Dalam Pelaporan Akuntansi Belanja Dinas Pekerjaan Umum Kota Kotamobagu Tahun Anggaran 2014.

Harahap, Sofyan Syafri. 2007. Analisis Kritis atas Laporan Keuangan. Jakarta:

PT Raja Grafindo Persada.

Khan, A. \& Mayes, S. 2009. Transition to Accrual Accounting, (Online). Diakses tanggal 28 Desember 2016.

Kieso, E. Donald, et al. 2008. Akuntansi Intermediate-Edisi 12. Erlangga: Jakarta

Langelo, Friska; Saerang, David; Alexander, Stanly. 2015. Analisis Penerapan Standar Akuntansi Pemerintahan Berbasis Akrual Dalam Penyajian Laporan Keuangan Pada Pemerintah Kota Bitung. Jurnal EMBA. Vol. 3 (1) : 1-8.

Mahsun, Mohammad. 2006. Pengukuran Kinerja Sektor Publik. Penerbit BPFE : Yogjakarta

Mardiasmo. 2009. Akuntansi Sektor Publik. ANDI : Yogyakarta.

Nordiawan, Deddi. 2006. Akuntani Sektor Publik. Jakarta: Salemba Empat.

Nordiawan, D., I. S. Putra dan M. Rahmawati. 2007. Akuntansi pemerintahan. Jakarta: Salemba Empat.

Sinaga, Jamason. 2005. Selamat Datang Standar Akuntansi Pemerintahan. 
Wijaya, H. 2008. Standar akuntansi pemerintah (PP No. 24 tahun 2005) untuk pengelolaan keuangan negara yang transparan dan akuntabel. Jurnal Akuntansi/Tahun XII No.3.313-323.

Widjajarso, Bambang. 2008. Penerapan Basis Akrual Pada Akuntansi Pemerintah Indonesia : Sebuah Kajian Pendahuluan. 